\title{
ARTICLE
}

\section{PENGEMBANGAN E-MODULE KIMIA BERBASIS POGIL (PROCESS ORIENTED GUIDED INQUIRY LEARNING) PADA MATERI REAKSI REDUKSI-OKSIDASI SEBAGAI SUMBER BELAJAR SISWA}

\author{
Retno Dwi Cahyaningrum ${ }^{1}$, Muktiningsih Nurjayadi ${ }^{2}$, Arif Rahman ${ }^{1}$ \\ ${ }^{1}$ Program Studi Pendidikan Kimia, ${ }^{2}$ Program Studi Kimia, Fakultas Matematika dan Ilmu \\ Pengetahuan Alam, Universitas Negeri Jakarta, Jl. Pemuda No. 10, Rawamangun 13220, \\ Jakarta, Indonesia \\ Corresponding author: r.dwicahya.rdc@gmail.com
}

\begin{abstract}
Abstrak
Penelitian ini bertujuan untuk menghasilkan e-Module kimia berbasis POGIL (Process Oriented Guided Inquiry Learning) pada materi reaksi reduksi-oksidasi sebagai sumber belajar siswa yang layak. Metode penelitian ini menggunakan penelitian dan pengembangan atau research and development $(R \& D)$. Subjek pada penelitian ini adalah siswa SMK kelas X. Teknik analisis data menggunakan analisis penilaian dari 10 validator terdiri dari 5 ahli materi dan bahasa, serta 5 ahli media. Analisis kuesioner uji validasi ahli, uji coba siswa dan guru menggunakan lembar kuesioner yang diadopsi dari Puskurbuk dan dikeluarkan oleh BSNP. Aplikasi yang digunakan dalam pembuatan e-Module adalah 3D PageFlip Professional 1.7.7. Hasil penelitian menunjukkan bahwa: (1) Penilaian oleh para ahli secara keseluruhan diperoleh berkisar 70\% hingga $90 \%$ dengan interpretasi baik hingga baik sekali, (2) Penilaian oleh guru dan siswa pada skala kecil dan skala besar secara keseluruhan meningkat diperoleh berkisar 80\% hingga 90\% dengan interpretasi baik hingga baik sekali. Dengan demikian, dapat disimpulkan bahwa e-Module kimia berbasis POGIL materi reaksi reduksi-oksidasi yang dikembangkan sangat baik dan sudah layak digunakan dalam proses pembelajaran dan dapat dijadikan sebagai sumber belajar mandiri siswa.
\end{abstract}

Kata Kunci : e-Module, POGIL, reaksi reduksi-oksidasi, sumber belajar, 3D PageFlip

\begin{abstract}
This study aims to produce chemical-based e-Module POGIL (Process Oriented Guided Inquiry Learning) on the material oxidation-reduction reaction as a viable source of student learning. This research method using research and development or research and development $(R \& D)$. Subjects in this study were students of SMK class X. Data analysis techniques using an assessment analysis of 10 validators consisting of 5 material and language experts, as well as 5 media experts. Analysis of expert validation test questionnaires, Student and teacher trials using questionnaires that were adopted from Puskurbuk and issued by BSNP. Applications used in the manufacture of e-Module is $3 D$ PageFlip Professional 1.7.7. The results of the study show that: (1) Assessment of experts as a whole is obtained in the range of $70 \%$ to $90 \%$ with good to excellent interpretation, (2) Assessment of teachers and students on a small scale and large scale as a whole increases in the range $80 \% 90 \%$ with good to good interpretation. Thus, it can be concluded that the e-Module POGIL material based chemical oxidation-reduction reactions are very well developed and already eligible for use in the learning process and can be used as a source of independent study students.
\end{abstract}

Keywords: e-Module, POGIL, oxidation-reduction reaction, learning resources, 3D PageFlip 


\section{PENDAHULUAN}

Pendidikan memiliki peranan yang penting dalam memajukan kualitas hidup bangsa, yang menuntut partisipasi dari berbagai pihak, terutama guru dan siswa. Guru sebagai pendidik harus mampu mencari dan mengembangkan inovasi dibidang pengajaran. Salah satu upaya inovasi dalam rangka meningkatkan kualitas pendidikan adalah meningkatkan kualitas sumber belajar. Sumber belajar yang baik adalah sumber belajar yang dirancang secara sistematis dan dikemas dengan penyajian menarik.

Penggunaan sumber belajar dan bahan ajar dalam pelaksanaan pembelajaran memungkinkan siswa dapat mempelajari materi secara runtut dan sistematis sehingga secara akumulasi mampu menguasai semua kompetensi secara utuh dan terpadu. Modul merupakan bentuk sumber belajar yang dapat memenuhi kebutuhan tersebut. Sumber belajar modul lebih banyak melibatkan peran siswa secara individual dibandingkan dengan guru. Hal ini sesuai dengan kurikulum 2013 yang menempatkan guru sebagai fasilitator kegiatan belajar dan membantu siswa memahami tujuan pembelajaran.

Observasi yang dilakukan pada November hingga Desember 2016 di SMK Negeri 26 Jakarta, diperoleh data tentang penggunaan buku pelajaran kimia di sekolah tersebut.Keingintahuan terhadap penggunaan buku pelajaran kimia yang digunakan oleh siswa yaitu untuk mengetahui sejauh mana buku tersebut dapat dimanfaatkan oleh siswa dengan baik dan dapat digunakan sebagai sumber belajar siswa.

Hasil observasi dari penyebaran kuesioner siswa, melibatkan 90 siswa kelas $\mathrm{X}$ diantaranya $\mathrm{X}$ TEK (Teknik Elektronika) 2, X TGB (Teknik Gambar Bangunan) 1, dan X TGB (Teknik Gambar Bangunan) 2, yaitu 73 siswa menyatakan sulit memahami buku pelajaran kimia yang digunakan. Kesulitan tersebut timbul karena buku pelajaran kimia menggunakan kalimat yang panjang, sehingga membutuhkan waktu yang cukup untuk memahami materi kimia. Sekolah memfasilitasi buku pelajaran kimia tersebut, untuk dipergunakan oleh siswa saat proses pembelajaran berlangsung, namun siswa tidak diperbolehkan membawa buku tersebut ke rumah. Akibatnya siswa tidak dapat mempelajari terlebih dahulu materi kimia yang akan dipelajarinya di kelas. Berdasarkan pernyataan tersebut dibuktikan bahwa 87 siswa membutuhkan bahan belajar lain yang digunakan untuk memahami materi kimia. Siswa perlu melakukan kegiatan belajar mandiri di luar pembelajaran di kelas yang ditunjang dengan bahan pembelajaran yang berkualitas dan menarik.

Menurut siswa, bahan pembelajaran yang menarik adalah penggunaan bahasa yang mudah dipahami dan dimengerti sehingga siswa tidak akan bingung atau rumit dalam mempelajari kimia. Selain itu siswa juga menginginkan terdapat gambargambar penunjang materi serta kegiatan praktikum. Siswa menyukai metode pengajaran menggunakan bahan ajar yang memberikan langkah-langkah penyelesaian soal dengan lengkap agar siswa dapat dengan mudah memahami konsep materi tersebut.

Mengatasi masalah tersebut, penulis melakukan penelitian pengembangan sumber belajar siswa berupa e-Module. e-Module yang akan dikembangkan bertujuan agar siswa dapat belajar secara mandiri. Keunggulan e-Module sebagai sumber belajar yang akan dikembangkan adalah penyajian ringkasan materi dengan tes formatif yang sistematis. Selain itu penyajian dalam e-Module terdapat gambar, video animasi, dan video praktikum guna membantu siswa memahami materi kimia dengan baik melalui audio visual.

E-Module yang akan dikembangkan oleh penulis menggunakan aplikasi pageflip 3 dimensi berbentuk flipbook, yang merupakan hasil pengembangan dari $e$ Module sebelumnya yang sudah ada dengan hanya berbentuk 2 dimensi. Siswa dalam menggunakan $e$-Module ini dibutuhkan laptop atau komputer. Berdasarkan analisis teknologi dari penyebaran kuesioner analisis kebutuhan siswa terhadap 90 siswa bahwa 87 
siswa mempunyai laptop, dengan demikian memudahkan penggunaan $e$-Module kimia.

Salah satu materi kimia yang sulit dipahami oleh siswa adalah reaksi reduksioksidasi (redoks), hal ini dibuktikan dari hasil observasi sebanyak 78 dari 90 siswa. Kesulitan dalam memahami materi tersebut karena banyak aturan-aturan dan konsep yang harus dihafal. Mengingat salah satu karakteristik materi reaksi redoks adalah konseptual. Berdasarkan sub-sub materi reaksi redoks, 81 siswa menyatakan sulit pada aturan dalam menentukan bilangan oksidasi, 71 siswa sulit pada persamaan reaksi redoks, kemudian 63 siswa juga sulit pada tata nama senyawa sederhana, dan 59 siswa sulit pada konsep reaksi redoks.

Sesuai dengan hasil observasi terkait pembelajaran Kimia yang dilakukan di SMK Negeri 26 Jakarta menunjukkan bahwa penggunaan metode pembelajaran yang digunakan oleh guru masih dominan konvensional, salah satunya adalah metode ceramah. Sebanyak 90 siswa menjadikan guru sebagai sumber informasi dan mencari sumber belajar dari internet untuk mengakses materi pembelajaran. Oleh karena itu, siswa kurang terlibat aktif dan mandiri dalam proses pembelajaran. Pada kurikulum 2013, guru sebagai fasilitator dan berpusat pada siswa, sehingga siswa dapat mengasah kemampuannya untuk berpikir kritis, aktif, dan mandiri.

Pemilihan metode pembelajaran efektif dapat digunakan sebagai salah satu alternatif solusi dalam upaya menyelesaikan

\section{METODOLOGI PENELITIAN}

Metode penelitian yang digunakan adalah penelitian pengembangan Research and Development. Menurut Borg and Gall educational research and development is process used to develop and validate educational product atau dapat diartikan bahwa penelitian pengembangan pendidikan adalah proses yang digunakan untuk mengembangkan dan memvalidasi produk pendidikan [1]. permasalahan di atas. Metode pembelajaran yang efektif menurut para ahli adalah metode pembelajaran yang menekankan proses mendapatkan pengetahuan (pembelajaran yang berdasarkan pada konstruktivisme) dan mengaitkan pengetahuan dengan pengalaman nyata dalam kehidupan sehari-hari [3].

Salah satu metode pembelajaran yang berdasarkan pada konstruktivisme yang telah dikembangkan Moog adalah metode pembelajaran Process Oriented Guided Inquiry Learning (POGIL). Metode inkuiri terbimbing berorientasi proses, menekankan pada pembelajaran kooperatif, siswa bekerja dalam tim, mendesain kegiatan untuk membangun kemampuan kognitif (conceptual understanding), dan mengembangkan keterampilan selama proses pembelajaran seperti proses sains, keterampilan berpikir, pemecahan masalah (problem solving), keterampilan komunikasi, menejemen, membangun sikap sosial yang positif dan keterampilan asesmen diri yang dapat mengembangkan pengetahuan metakognitif [3].

Berdasarkan referensi dan permasalahan yang diperoleh saat observasi, maka dipandang oleh penulis perlu melakukan penelitian pengembangan dengan judul "Pengembangan e-Module kimia berbasis POGIL (Process Oriented Guided Inquiry Learning) pada materi reaksi reduksi-oksidasi sebagai sumber belajar", yang nantinya diharapkan dapat dipergunakan siswa sebagai sumber belajar siswa.

Adapun tahap penelitian dan pengembangan yang dikemukakan oleh Borg dan Gall yaitu (1) Penelitian dan pengumpulan informasi, (2) Perencanaan, (3) Pengembangan $e$-Module awal, (4) Uji validasi e-Module para ahli, (5) Revisi $e$ Module uji validasi, (6) Uji coba pada skala kecil, (7) Revisi e-Module uji skala kecil, (8) Uji coba pada skala besar, (9) Revisi $e$ Module akhir [1]. 
Penelitian ini mengembangkan sumber belajar siswa berupa $e$-Module kimia berbasis POGIL (Process Oriented Guided Inquiry Learning). Produk e-Module ini menggunakan bentuk flipbook. Flipbook adalah sebuah buku dengan serangkaian gambar-gambar yang bervariasi secara bertahap dari satu halaman ke halaman

\section{TEKNIK ANALISA DATA}

Skala penilaian yang digunakan dalam instrumen penelitian ini merupakan adopsi dari Puskurbuk (Pusat Kurikulum dan Perbukuan) dengan menggunakan 10 tingkatan, seperti pada Tabel 1 berikut.

Tabel 1 Interpretasi Deskriptif dengan Skala Penilaian

\begin{tabular}{|c|c|c|c|c|c|c|c|c|c|}
\hline $\begin{array}{c}\text { Kurang } \\
\text { sekali }\end{array}$ & \multicolumn{3}{|c|}{ Kurang } & \multicolumn{4}{c|}{ Baik } & \multicolumn{2}{c|}{$\begin{array}{c}\text { Baik } \\
\text { sekali }\end{array}$} \\
\hline 1 & 2 & 3 & 4 & 5 & 6 & 7 & 8 & 9 & 10 \\
\hline
\end{tabular}

Data yang terkumpul diproses dengan cara dijumlahkan, dibandingkan dengan jumlah yang diharapkan dan diperoleh presentase kelayakan [4] dengan rumus :

$$
\%=\frac{\sum \text { skor yang diperoleh }}{\sum \text { skor maksimal }} \times 100 \%
$$

Hasil perhitungan persentase kelayakan dikategorikan sesuai dengan interpretasi menggunakan skala penilaian seperti pada Tabel 2 berikut.

Tabel 2 Interpretasi Deskriptif Kualitas dengan Skala Penilaian

\begin{tabular}{|c|c|}
\hline Persentase & Interpretasi \\
\hline $0 \%-29 \%$ & Kurang Sekali \\
\hline $30 \%-59 \%$ & Kurang Baik \\
\hline $60 \%-89 \%$ & Baik \\
\hline $90 \%-100 \%$ & Baik Sekali \\
\hline
\end{tabular}

Data hasil penilaian para ahli yang diperoleh akan diuji reliabilitas antar rater. Reliabilitas ini mengacu pada konsistensi evaluasi dari 2 atau lebih penilai terhadap $e$ Module yang sama. Tujuan uji reliabilitas untuk mengetahui kekonsistensian antar berikutnya, sehingga ketika halaman yang berubah cepat, gambar-gambar muncul untuk menghidupkan dengan mensimulasikan gerakan atau beberapa perubahan lainnya. Jenis software utama yang digunakan untuk membuat $e$-Module ini adalah 3D PageFlip Professional 1.7.7.

rater dalam menilai standar kontekstual [5]. Uji statistik yang digunakan untuk menghitung reliabilitas pada penelitian ini menggunakan uji Hoyt dengan rumus:

$$
r=\frac{R J K_{B}-R J K_{E}}{R J K_{B}}
$$

Sumber: Djaali, 2008 [2]

Keterangan:

$r \quad$ : Reliabilitas kesesuaian antar rater

$R J K_{B} \quad$ : Rata-rata jumlah Kuadrat Baris

$R J K_{E} \quad$ : Rata-rata jumlah Kuadrat Error

\section{HASIL DAN PEMBAHASAN}

Pengembangan e-Module ini dibuat menggunakan aplikasi 3D PageFlip Professional 1.7.7.

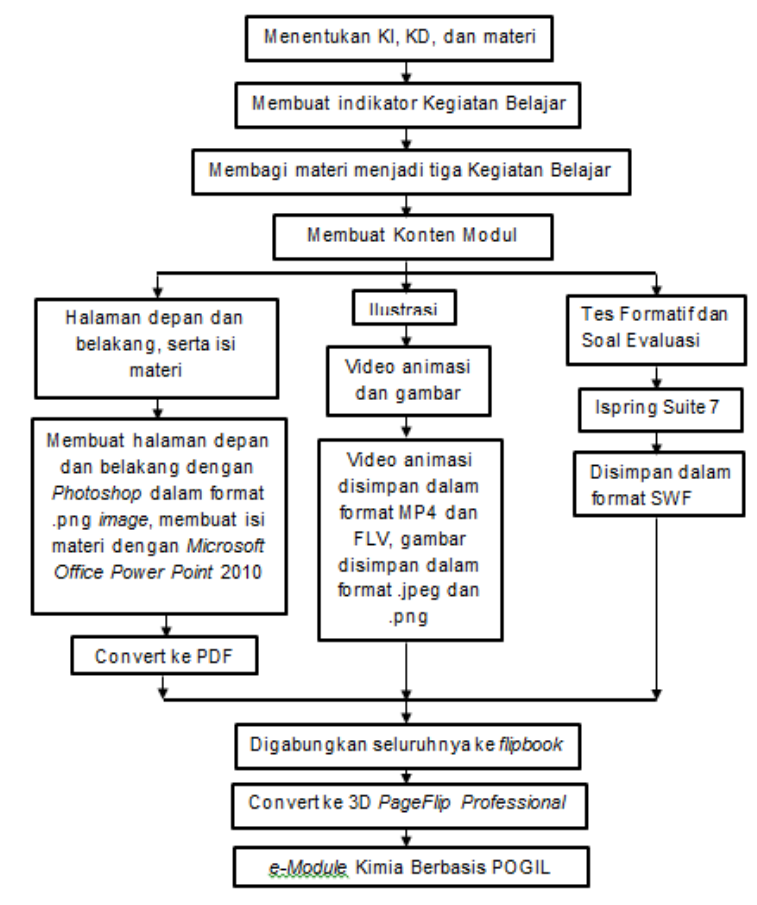

Gambar 1 Alur Pembuatan e-Module 
Aplikasi 3D PageFlip Professional 1.7.7 memiliki kelebihan yaitu tampilan yang sangat menarik, navigasi yang lengkap, efek membalik modul digital lebih

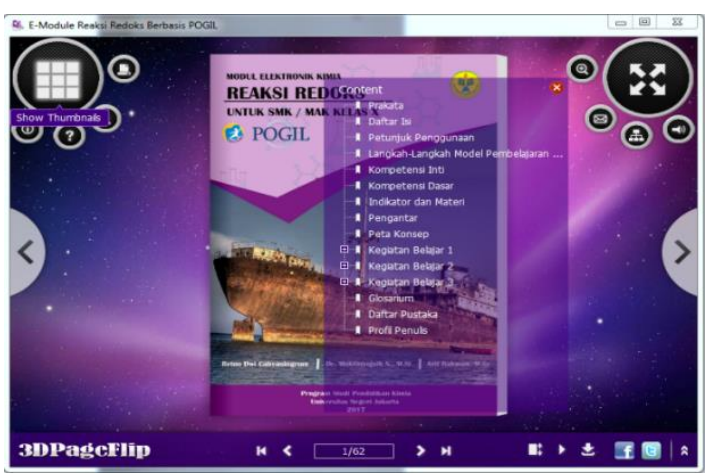

Gambar 2 Tampilan Halaman Depan e-Module

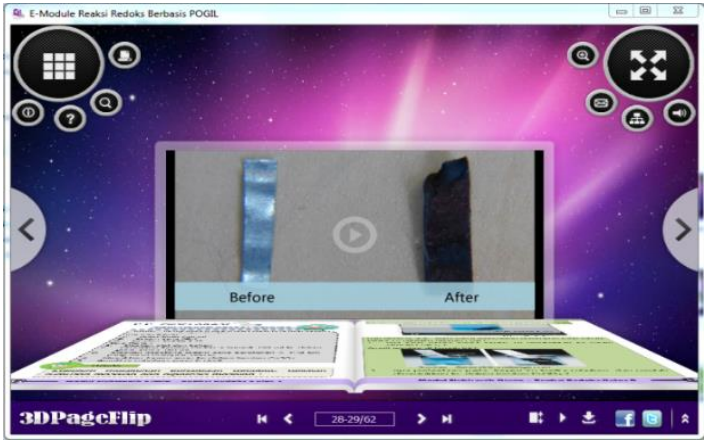

Gambar 3 Tampilan Video

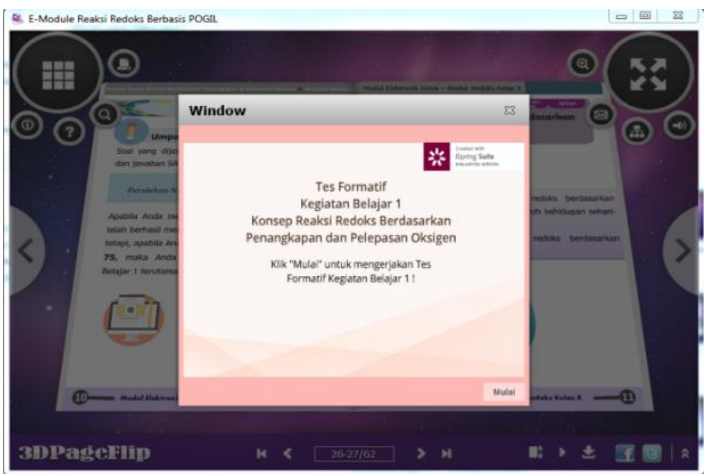

Gambar 4 Tampilan Tes Formatif

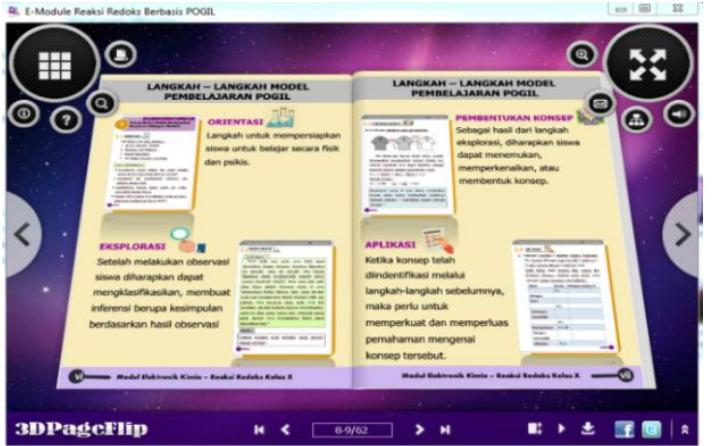

Gambar 5 Tampilan Langkah-Langkah POGIL nyata, serta tampilan video yang lebih jelas. Berikut ini merupakan beberapa tampilan halaman pada e-Module kimia berbasis POGIL:

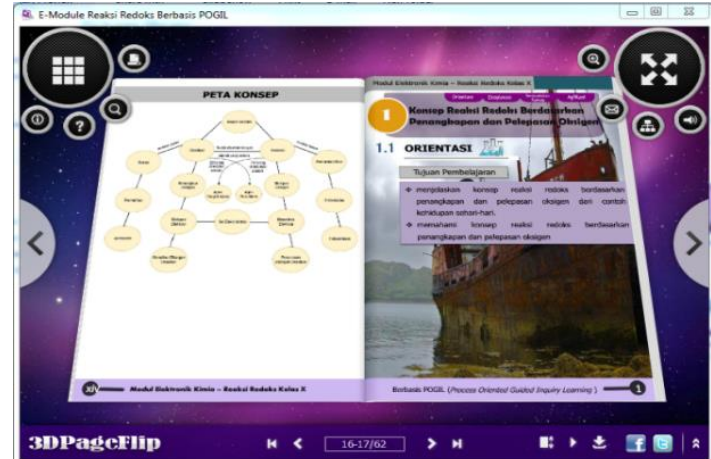

Gambar 6 Tampilan Tahap Orientasi

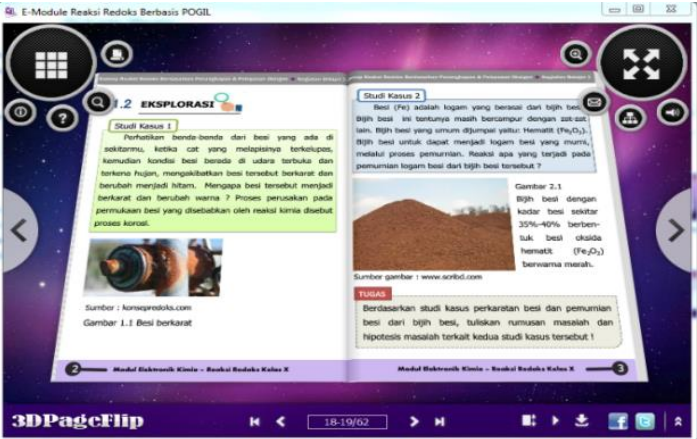

Gambar 7 Tampilan Tahap Eksplorasi

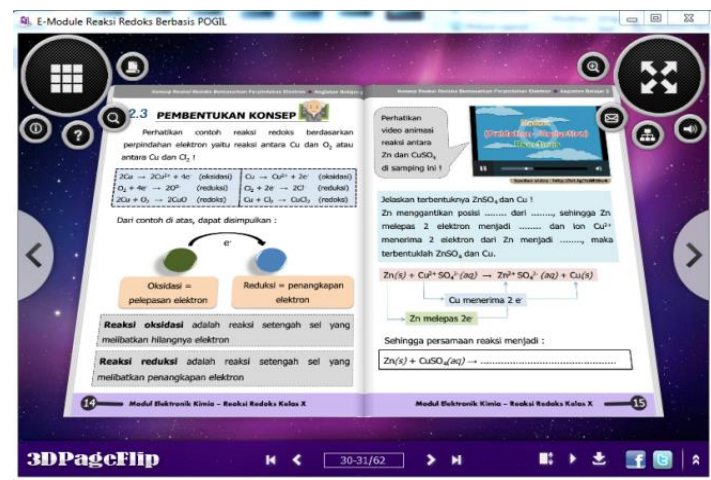

Gambar 8 Tampilan Tahap Pembentukan Konsep

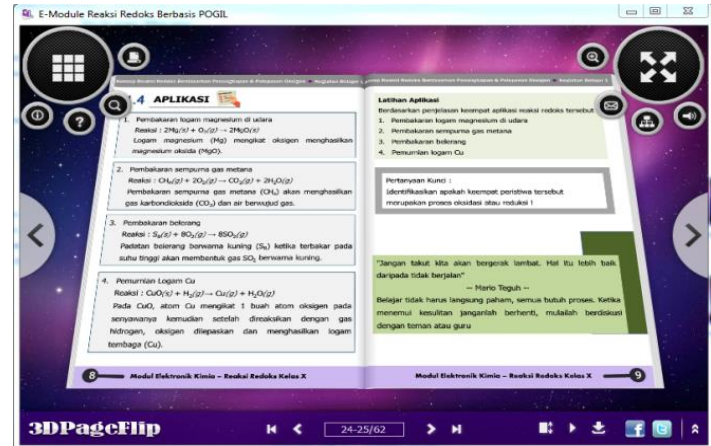

Gambar 9 Tampilan Aplikasi 
Hasil validasi e-module Kimia oleh ahli materi, bahasa, dan media menunjukkan persentase capaian sebesar $90 \%$ dengan interpretasi baik sekali. Berikut ini Tabel 4 menunjukkan indikator yang diukur pada aspek materi, bahasa, dan media, serta pada Tabel 5 menunjukkan hasil rentang persentase kelayakan oleh ahli.

Tabel 4 Indikator yang Diukur

\begin{tabular}{|c|l|}
\hline No. & \multicolumn{1}{|c|}{ Materi dan Bahasa } \\
\hline $\mathbf{1}$ & Cakupan Materi \\
\hline $\mathbf{2}$ & Keakuratan Materi \\
\hline $\mathbf{3}$ & Keterampilan \\
\hline $\mathbf{4}$ & $\begin{array}{l}\text { Sesuai dengan Perkembangan Peserta } \\
\text { Didik }\end{array}$ \\
\hline $\mathbf{5}$ & Komunikatif \\
\hline $\mathbf{6}$ & Kemampuan Memotivasi \\
\hline $\mathbf{7}$ & Kelugasan \\
\hline $\mathbf{8}$ & Koherensi dan Keruntutan Alur Pikir \\
\hline $\mathbf{9}$ & $\begin{array}{l}\text { Kesesuaian dengan Kaidah Bahasa } \\
\text { Indonesia }\end{array}$ \\
\hline $\mathbf{1 0}$ & $\begin{array}{l}\text { Penggunaan Istilah dan Simbol/ } \\
\text { Lambang Kimia }\end{array}$ \\
\hline \multicolumn{2}{|c|}{ Media } \\
\hline $\mathbf{1}$ & Tata Letak Kulit $e$-Module \\
\hline $\mathbf{2}$ & $\begin{array}{l}\text { Huruf yang digunakan menarik dan } \\
\text { mudah dibaca }\end{array}$ \\
\hline $\mathbf{3}$ & Huruf yang sederhana \\
\hline $\mathbf{4}$ & Isi Cover $e$-Module \\
\hline $\mathbf{5}$ & Tata Letak Konsisten \\
\hline $\mathbf{6}$ & Unsur Tata Letak Harmonis \\
\hline $\mathbf{7}$ & $\begin{array}{l}\text { Penempatan dan Penampilan Unsur } \\
\text { Tata Letak }\end{array}$ \\
\hline $\mathbf{8}$ & Tata Letak Mempercepat Pemahaman \\
\hline $\mathbf{9}$ & Tipografi Sederhana \\
\hline $\mathbf{1 0}$ & Tipografi Mudah Dibaca \\
\hline $\mathbf{1 1}$ & Tipografi Memudahkan Pemahaman \\
\hline $\mathbf{1 2}$ & $\begin{array}{l}\text { Ilustrasi Memperjelas dan } \\
\text { Mempermudah Pemahaman }\end{array}$ \\
\hline $\mathbf{1 3}$ & Ilustrasi Isi Menimbulkan Daya Tarik \\
\hline
\end{tabular}

Berdasarkan hasil penilaian uji coba $e$-Module reaksi redoks oleh guru skala besar, pada seluruh indikator penilaian mengalami peningkatan, dimana hasil rentang penilaian e-Module secara keseluruhan pada guru skala besar memiliki persentase penilaian sebesar $75 \%$ hingga 95\% dengan interpretasi baik hingga baik sekali.
Tabel 5 Hasil Rentang Persentase Kelayakan oleh Ahli

\begin{tabular}{|c|l|c|c|c|c|c|}
\hline \multirow{2}{*}{ No } & \multirow{2}{*}{ Indikator } & \multicolumn{5}{|c|}{ Persentase Guru } \\
\cline { 2 - 7 } 1 & $\mathbf{1}$ & $\mathbf{2}$ & $\mathbf{3}$ & $\mathbf{4}$ & $\mathbf{5}$ \\
\hline & $\begin{array}{l}\text { Kesesuaian } \\
\text { Materi } \\
\text { dengan } \\
\text { Kurikulum } \\
\text { 2013 }\end{array}$ & 92,5 & 87,5 & 90 & 82,5 & 95 \\
\hline 2 & $\begin{array}{l}\text { Kejelasan Isi } \\
\text { Modul }\end{array}$ & 93,3 & 88,3 & 81,7 & 80 & 92 \\
\hline 3 & $\begin{array}{l}\text { Fungsi Soal } \\
\text { Sebagai Alat } \\
\text { Evaluasi }\end{array}$ & 95 & 90 & 90 & 75 & 90 \\
\hline 4 & $\begin{array}{l}\text { Penggunaan } \\
\text { Bahasa }\end{array}$ & 94,3 & 88,6 & 90 & 80 & 91 \\
\hline 5 & $\begin{array}{l}\text { Desain } \\
\text { Tampilan }\end{array}$ & 90 & 85 & 85 & 80 & 85 \\
\hline
\end{tabular}

Berikut ini Tabel 6 dan Tabel 7 menunjukkan hasil penilaian uji coba $e$ Module oleh guru kimia dan siswa:

Tabel 6 Hasil Penilaian Uji Coba e-Module Reaksi Redoks Berbasis POGIL (Process Oriented Guided Inquiry Learning) oleh Guru Skala Besar

\begin{tabular}{|c|c|c|c|c|c|c|}
\hline \multirow{2}{*}{ No } & \multirow{2}{*}{$\begin{array}{c}\text { Aspek } \\
\text { Penilaian } \\
\text { Ahli }\end{array}$} & \multicolumn{5}{|c|}{$\begin{array}{c}\text { Rentang Persentase Kelayakan } \\
(\%)\end{array}$} \\
\hline & & $\begin{array}{c}\text { Ahli } \\
1\end{array}$ & $\begin{array}{c}\text { Ahli } \\
2\end{array}$ & $\begin{array}{c}\text { Ahli } \\
3\end{array}$ & $\begin{array}{c}\text { Ahli } \\
4\end{array}$ & $\begin{array}{c}\text { Ahli } \\
5\end{array}$ \\
\hline 1 & $\begin{array}{l}\text { Materi } \\
\text { dan } \\
\text { Bahasa }\end{array}$ & $\begin{array}{l}75- \\
90\end{array}$ & $\begin{array}{r}80- \\
93,3\end{array}$ & $\begin{array}{c}80- \\
90\end{array}$ & 80 & $\begin{array}{l}75- \\
90\end{array}$ \\
\hline 2 & Media & $\begin{array}{l}86,7 \\
-90\end{array}$ & $\begin{array}{l}78- \\
90\end{array}$ & $\begin{array}{l}75- \\
90\end{array}$ & $\begin{array}{l}72- \\
90\end{array}$ & $\begin{array}{r}75- \\
83,3\end{array}$ \\
\hline
\end{tabular}

Tabel 7 Hasil Penilaian Uji Coba e-Module Reaksi Redoks Berbasis POGIL (Process Oriented Guided Inquiry Learning) oleh Siswa Skala Besar

\begin{tabular}{|c|l|c|c|}
\hline No & \multicolumn{1}{|c|}{ Indikator } & $\mathbf{\%}$ & Interpretasi \\
\hline 1 & $\begin{array}{l}\text { Kesesuaian Materi } \\
\text { dengan Kurikulum } \\
2013\end{array}$ & 88.18 & Baik \\
\hline 2 & Kejelasan Isi Modul & 87.00 & Baik \\
\hline 3 & $\begin{array}{l}\text { Fungsi Soal Sebagai } \\
\text { Alat Evaluasi }\end{array}$ & 86.56 & Baik \\
\hline 4 & Penggunaan Bahasa & 86.09 & Baik \\
\hline 5 & Desain Tampilan & 90.50 & Baik Sekali \\
\hline $\begin{array}{l}\text { Rata-Rata Persentase } \\
\text { Penilaian Uji Coba }\end{array}$ & $\mathbf{8 7 . 6 7}$ & Baik \\
\hline
\end{tabular}

Berdasarkan hasil penilaian uji coba $e$ Module reaksi redoks oleh siswa skala 
besar, pada seluruh indikator penilaian mengalami peningkatan, dimana hasil ratarata penilaian e-Module secara keseluruhan pada siswa skala besar memiliki persentase penilaian sebesar $87,67 \%$ dengan interpretasi baik.

\section{KESIMPULAN}

Berdasarkan hasil penilaian dari para ahli, uji coba pada siswa, dan guru secara keseluruhan memiliki interpretasi baik hingga baik sekali. Hal ini dibuktikan dari rentang persentase kelayakan pada uji validasi oleh ahli yaitu $75 \%$ hingga $90 \%$ dan rentang persentase pada uji coba skala besar yaitu pada siswa $87,67 \%$ dan pada guru $95 \%$, sehingga dapat disimpulkan bahwa $e$-Module yang dikembangkan layak digunakan dalam proses pembelajaran di kelas dan dapat dijadikan sebagai sumber belajar mandiri siswa. e-Module yang dikembangkan sesuai dengan kebutuhan siswa maupun guru dalam proses pembelajaran kimia pada materi reaksi redoks dengan bahasa yang mudah dipahami siswa, memuat isi materi yang lengkap dengan kegiatan dan contoh nyata dalam kehidupan sehari-hari, tes formatif, evaluasi, dan soal-soal yang disertai pembahasan, serta memiliki tampilan yang menarik dengan adanya video animasi dan gambar. e-Module yang dikembangkan dengan metode pembelajaran POGIL (Process Oriented Guided Inquiry Learning), yaitu salah satu pembelajaran kurikulum 2013 yang memiliki 4 tahapan, diantaranya orientasi, eksplorasi, pembentukan konsep, dan aplikasi.

\section{DAFTAR PUSTAKA}

[1] Borg, W.R. \& Gall, M.D. Educational Research: An In troduction. NewYork: Longman Inc, 1989.

[2] Djaali \& Muljono, P. Pengukuran dalam Bidang Pendidikan. Jakarta: Grasindo, 2008.

[3] Hanson, David M. Instructor's Guide to Process-Oriented Guided-Inquiry Learning. Stony Brook University: Pacifi'c Crest, 2006.

[4] Sugiyono. Metode Penelitian Kuantitatif, Kualitatif, dan $R \& D$. Bandung: Alfabeta, 2015.

[5] Widhiarso, W. Mengestimasi Reliabilitas. Yogyakarta: Fakultas Psikologi UGM, 2005. 